\title{
Mardin'de Satılan Çiğ Sütlerin Bazı Fizikokimyasal ve Mikrobiyolojik Özellikleri
}

\author{
Aslı ÇELIKEL GÜNGÖR ${ }^{1, a^{*}}$, Semra GÜRBÜZ ${ }^{1, b}$, Musa Serdar AKIN²,c, Mutlu Buket AKIN²,d Büşra \\ PALABIÇAK ${ }^{2, \mathrm{e}}$ \\ aORCID: 0000-0003-0583-295X, bORCID: 0000-0002-7099-0308, 'ORCID: 0000-0001-7569-1983, dORCID: 0000-0001-8307- \\ 8521, eORCID: 0000-0002-0983-8577
}

\begin{abstract}
${ }^{1}$ Mardin Artuklu Üniversitesi, Turizm Fakültesi, Gastronomi ve Mutfak Sanatları Bölümü, Mardin, Türkiye. ${ }^{2}$ Harran Üniversitesi, Mühendislik Fakültesi, Gıda Mühendisliği Bölümü, Şanlıurfa, Türkiye.
\end{abstract}

Geliş Tarihi: 07.11.2019

Kabul Tarihi: 05.06.2020

Özet:Bu çalışmada Mardin'de satışa sunulan toplam 40 çiğ süt örneğinin bazı fizikokimyasal ve mikrobiyolojik özellikleri incelenmiştir. Süt örneklerinin $\mathrm{pH}$ değerinin ortalaması 6.56, titrasyon asitliğinin \%0.191, yoğunluğunun $1.029 \mathrm{~g} \mathrm{ml}^{-1}$, kurumadde miktarının \%12.46, yağsız kurumadde miktarının \%8.89, yağ miktarının \%3.57, protein miktarının \%3.07, kül miktarının \%0.72, TAMB sayısının 6.62 log kob ml-1, koliform bakteri sayısının 4.98 log kob $\mathrm{ml}^{-1}$ ve küf-maya sayısının 4.87 $\log \mathrm{kob} \mathrm{ml}^{-1}$ olduğu tespit edilmiştir. Çalışmada incelenen çiğ süt örneklerinde yapılan analizlerde örneklerin kalitelerinin yeterli düzeyde olmadığı, önemli bir kısmının (\%95'inin) Türk Gıda Kodeksi Çiğ Sütün Arzına Dair Tebliğ'ine uymadığı belirlenmiştir.

Anahtar Kelimeler: Süt, Mikrobiyolojik özellik, Fizikokimyasal özellik.

\section{Some Physicochemical and Microbiological Properties of Raw Milk Sold in Mardin}

\begin{abstract}
In this study, some physicochemical and microbiological properties of 40 raw milk samples sold in Mardin were investigated. As the average of the milk samples examined $\mathrm{pH}$ value 6.56 , titration acidity $0.191 \%$, density $1.029 \mathrm{~g} \mathrm{ml}^{-1}$, dry matter amount $12.46 \%$, dry fat content $8.89 \%$, fat amount $3.57 \%$, protein amount $3.07 \%$, ash amount $0.72 \%$, the number of

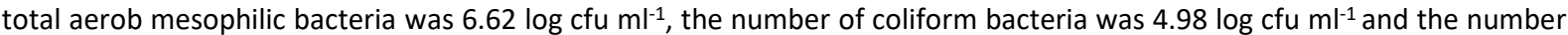
of mold-yeast was $4.87 \mathrm{log} \mathrm{cfu} \mathrm{ml}^{-1}$. In the analysis of raw milk samples, it was determined that the quality of the samples was not sufficient and that a significant part (95\%) did not comply with the Turkish Food Codex Communiqué on the Supply of Raw Milk.
\end{abstract}

Keywords: Milk, Microbiological properties, Physicochemical properties.

\section{Giriş}

Süt içeriğindeki immünoglobulinler, enzimler, enzim inhibitörleri, hormonlar, antibakteriyel ajanlar gibi protein ve peptit yapılı öğeler ile yağ asitleri, vitamin ve minerallerden dolayı canlının büyüme ve gelişmesinde önemli bir role sahiptir (Beykaya ve ark., 2017; Fox ve McWeeney, 2003; Maijala, 2000; Miller ve ark., 2000). Ayrıca süt mikroorganizma için de iyi bir gelişme ortamıdır. Özellikle çiğ süte üretim ve depolanması sırasında bulaşan çeşitli mikroorganizmalar, hızlı bir şekilde gelişmekte ve sütte istenmeyen değişikliklere neden olabilmektedir. Bu nedenle süt, sağımın hemen ardından soğutulmalı ve içme sütüne ya da diğer süt ürünlerine işlenmelidir (Köşer ve Tunail, 1985; Tekinşen, 1996).

Ülkemizde üretilen süt miktarı 22 milyon ton civarındadır (TüiK, 2018). Türkiye'de üretilen sütün yaklaşık \%49'u yakını sanayide işlenerek tüketime sunulmakta, \%32'si hanede içme sütü ve süt ürünü (peynir, yoğurt vb.) şeklinde kullanılmakta ve \%11'i mandıralar dışında direk olarak satılmaktadır (Anonim, 2016). Herhangi bir ısıl işlem (pastörizasyon ve UHT) geçirmemiş süt (çiğ süt/ sokak sütü/ açık süt) uygun koşullarda sağılmadığında ve depolanmadığında insan sağığını tehdit eden çeşitli hastalık etkenlerini içerebilmektedir (Akın ve ark., 2016). Ülkemizde süt ve süt ürünlerine ait standartlar ve bu standartların denetlenmesine dair yasa ve yönetmelikler olmasına rağmen üretilen sütün büyük bir kısmının uygun olmayan koşullarda tüketiciye ulaşması halk sağlığı açısından sorun oluşturmaktadır (Kesenkaş ve Akbulut, 2010). Ülkemizde çiğ sütün yerel perakendeciler tarafından son tüketiciye arzına ilişkin hususlar Türk Gıda Kodeksi Çiğ Sütün Arzına Dair Tebliğ'de belirtilmektedir (Anonim, 2017). Bu araştırmada, Mardin'de yerel perakendeciler tarafından satışa sunulan çiğ inek sütlerinin bazı fizikokimyasal ve mikrobiyolojik özelliklerinin tespit edilmesi ve sütlerin kalitesinin değerlendirilmesi 
amaçlanmıştır. Elde edilen sonuçların daha önce yapılan benzer araştırmalar ile karşılaştırılmasıyla çiğ sütlerin (sokak sütü) kalitelerinde bir gelişme olup olmadığını belirlenecektir. Ayrıca araştırmamız satışa sunulan çiğ sütlerin Türk Gıda Kodeksi Çiğ Sütün Arzına Dair Tebliğ'e uygunluğunu ortaya koymak açısından önem taşımaktadır.

\section{Materyal ve Metot}

Araştırmanın materyalini Şubat 2018 tarihinde Mardin'de farklı noktalarda satışa sunulan toplam 40 çiğ inek sütü oluşturmuştur. Süt örnekleri 500 ml'lik steril cam şişelere yaklaşık 200-300 ml kadar alınmış ve soğukta muhafaza edilerek, Mardin Artuklu Üniversitesi Sağlık Meslek Yüksekokulu laboratuvarlarına getirilmiş ve sütlerde aşağıda belirtilen analizler yapılmıştır.

Fizikokimyasal analizler:Çiğ sütlerinin $\mathrm{pH}$ değerleri pH metre kullanılarak, asitlik değeri alkali titrasyon yöntemi ile belirlenmiştir (Oysun, 2011). Çiğ sütlerde kurumadde oranı gravimetrik yönteme göre ve yağ oranı 0-8 taksimatlı özel süt bütirometresi ile Gerber yöntemine göre belirlenmiştir (Anonim, 1989; IDF, 1982). Süt örneklerinde yağsız kurumadde oranı, toplam kurumadde değerinden yağ değerinin çıkarılmasıyla belirlenmiştir (Metin, 2010). Protein oranı, mikro Kjeldahl yöntemi ile azot miktarlarının saptanması ve bulunan azot miktarının 6,38 faktörü ile çarpılması ile hesaplanmıştır (Metin, 1998). Süt örneklerinde yoğunluk tayini laktodansimetre ile saptanmıştır (Oysun, 2011).

Mikrobiyolojik Analizler:Süt örnekleri toplam aerobik mezofilik bakteri (TAMB) sayısının belirlenmesi amacıyla Plate Count Agar, (Merck) koliform bakteri sayısının belirlenmesi amacıyla Violet Red Blie Agar (Merk) ve maya-küf sayısının belirlenmesi amaciyla Potato Dextrose Agar besiyerine dökme plak yöntemi kullanılarak paralel ekim yapılmıştır. Petri kutuları TAMB sayımı için $32^{\circ} \mathrm{C}^{\prime}$ de 48 saat, koliform bakteri sayımı için $37^{\circ} \mathrm{C}$ de 24 saat süre ve küf-maya sayımı için $25^{\circ} \mathrm{C}$ de 5 gün inkübe edilmiş ve sayım sonuçlar logaritmik transformasyona tabii tutulduktan sonra log kob $\mathrm{ml}^{-}$ ${ }^{1}$ olarak verilmiştir (Köşer ve Tunail, 1985).

\section{Bulgular}

Araştırmada incelenen süt örneklerinin bazı fizikokimyasal ve mikrobiyolojik özeliklerine ait değerler Tablo 1 ve Tablo 2'de verilmiştir. Yapılan analiz sonucunda çiğ süt örneklerinin ortalama $\mathrm{pH}$ değeri 6.56, titrasyon asitliği \%0.191, yoğunluğu $1.029 \mathrm{~g} \mathrm{ml}^{-1}$, kurumadde miktarı \%12.46, yağsız kurumadde miktarı \%8.89, yağ miktarı \%3.57, protein miktarı \%3.07, kül miktarı \%0.72 olarak belirlenmiştir. Örneklerin TAMB sayısının $6.62 \mathrm{log}$ kob $\mathrm{ml}^{-1}$, koliform bakteri sayısının $4.98 \mathrm{log}$ kob $\mathrm{ml}^{-1}$ ve küf-maya sayısının $4.87 \mathrm{log} \mathrm{kob} \mathrm{ml}^{-1}$ olduğu saptanmıştır.

Tablo 1. Süt örneklerinin fizikokimyasal özelikleri

\begin{tabular}{lccccccccc}
\hline & pH & $\begin{array}{c}\text { Asitlik } \\
(\% \text { LA.) }\end{array}$ & $\begin{array}{c}\text { Yoğunluk } \\
\left(\mathrm{g} \mathrm{ml}^{-1}\right)\end{array}$ & $\begin{array}{c}\text { Kurumadde } \\
(\%)\end{array}$ & $\begin{array}{c}\text { Kağsummadde } \\
(\%)\end{array}$ & $\begin{array}{c}\text { Yağ } \\
(\%)\end{array}$ & $\begin{array}{c}\text { Protein } \\
(\%)\end{array}$ & $\begin{array}{c}\text { Kül } \\
(\%)\end{array}$ \\
\hline En düșük & 6.28 & 0.133 & 1.023 & 10.96 & 8.34 & 2.00 & 2.41 & 0.61 \\
En yüksek & 6.80 & 0.276 & 1.033 & 13.85 & 9.89 & 4.50 & 3.66 & 0.83 \\
& & & & & & & & & \\
Ortalama & 6.56 & 0.191 & 1.029 & 12.46 & 8.89 & 3.57 & 3.07 & 0.72 \\
\hline
\end{tabular}

Tablo 2. Süt örneklerinin mikrobiyolojik özelikleri

\begin{tabular}{|c|c|c|c|}
\hline & Toplam Aerob & & \\
\hline & $\begin{array}{c}\text { Mezofilik Bakteri } \\
\text { (log kob ml-1) }\end{array}$ & $\begin{array}{c}\text { Koliform Bakteri } \\
\text { (log kob ml-1) }\end{array}$ & $\begin{array}{c}\text { Maya-Küf } \\
(\log \text { kob ml-1) }\end{array}$ \\
\hline En düşük & 4.30 & 2.00 & 3.00 \\
\hline En yüksek & 8.66 & 6.75 & 7.65 \\
\hline Ortalama & 6.62 & 4.98 & 4.87 \\
\hline
\end{tabular}

\section{Tartışma ve Sonuç}

Çalışmamızda çiğ sütlerin taşıması gereken özellikler Türk Gıda Kodeksi Çiğ Sütün Arzına Dair Tebliğ'de belirtilen değerler kapsamında değerlendirilmiştir (Anonim, 2017). Bu tebliğ kapsamında çiğ inek sütlerinin titrasyon asitliği değerlerinin \% süt asidi cinsinden \%0.135-0.200 arasında, protein değerlerinin en az \%2.8, yağ değerinin en az \%3.4, yağsız kurumadde değerinin en az \%8.5 ve yoğunluğunun $1.028 \mathrm{~g} \mathrm{ml}^{-1}$ olması gerektiği belirtilmiştir. Aynı tebliğde çiğ inek sütünün tesadüfi örnekleme ile yapılan kontrollerde toplam canlı bakteri sayısının $30^{\circ} \mathrm{C}^{\prime}$ de 100.000 adet $\mathrm{ml}^{-1}$ den daha düşük olması gerektiği bildirilmiştir (Anonim, 2017).

pH değerleri:Sütün $\mathrm{pH}$ değeri sütün dissosiye kısmında hidrojen iyonlarının miktarı ve aktivitesine bağı olarak ürünün kalitesi ve randımanı hakkında bilgi sahibi olunması açısından önem taşımaktadır. Yeni sağılmış inek sütünün $\mathrm{pH}$ değeri 6.6-6.8 arasındadır. Süttün $\mathrm{pH}$ değerinin $6.8^{\prime}$ in üzerinde olması mastitis hastalığının ya da süte nötralize edici madde ilavesinin $6.5^{\prime}$ in altında olması ağız sütünün ya da aşırı asitlik artışının göstergesi olarak kabul edilmektedir (Metin, 2005). Mardin'de satışa sunulan çiğ süt örneklerinin $\mathrm{pH}$ değerinin 6.28 ile 6.80 arasında değiştiği ve ortalama değerin 6.56 olduğu tespit edilmiştir. Göncü ve ark. (2017), Şanlıurfa'da satışa sunulan sokak sütlerin ortalama $\mathrm{pH}$ değerlerinin yaz ve kış dönemlerinde sırasıyla 6.54 ve 6.46 olduğunu bildirmişlerdir. Kesenkaş ve Akbulut (2010), İzmir'den toplanan çiğ süt örneklerinin $\mathrm{pH}$ değerinin 6.30 ile 7.00 arasında 
olduğunu saptamışlardır. Çalışmamızda belirlenen çiğ süt pH değerleri, Göncü ve ark. (2017) ile Kesenkaş ve Akbulut (2010) buldukları değerler ile benzerlik göstermektedir.

Titrasyon Asitliği Değeri:Sütün asitliği önemli kalite parametrelerinden biridir. Sütün asidik özelliği içeriğinde bulunan albümin, globülin, karbondioksit, kazein, fosfat ve sitratlardan kaynaklanmaktadır. Sütte bulunan başta laktik asit bakterileri olmak üzere mikroorganizmalar süttün depolanması sırasında sütte bulunan laktozun laktik asite dönüşmesine neden olmakta ve süt asitliğini etkilemektedir. Sütün asitlik değerinin laktik asit cinsinden \%0.200'nin üzerinde olması sütte mikrobiyal gelişmenin fazla olduğunun, \%0.110’nın altında olması negatif bir mikrobiyal gelişmenin, hayvanda meme hastalığının ya da yanlış yemleme uygulamasının göstergesi olarak kabul edilmektedir (Kesenkaş ve Akbulut, 2010). Ayrıca sütte asitliğin fazla düşük olması soda veya hidrojen peroksit gibi koruyucu maddelerin katıldığı kuşkusuna neden olmaktadır (Kurt ve ark., 1993; Metin, 2005). Çalışmada analize alınan süt örneklerinin titrasyon asitliği değerlerinin laktik asit cinsinden minimum $\% 0.133$ ve maksimum \%0.276 olduğu tespit edilmiştir. Sütlerin ortalama asitlik değerinin \%0.191 olarak belirlenmiştir. Yapılan benzer çalışmalar incelendiğinde Beykaya ve ark. (2017), 50 adet çiğ süt örneğinin asitlik değerlerinin laktik asit cinsinden $\% 0.135$ ile \%0.495 arasında, ortalama değerin \%0.233 olduğunu, Akın ve ark. (2016), Adıyaman ilinde mevsimsel olarak toplanan çiğ sütlerde ortalama asitlik değerinin çiftlik sütlerinde $\% 0.161$ ile $\% 0.170$ arasında ve sokak sütlerinde $\% 0.182$ ile \%0.220 arasında değiştiğini bildirmişlerdir. Mardin'den toplanan çiğ süt örneklerinin 10 tanesinin Çiğ Sütün Arzına Dair Tebliğ'de belirtilen değerlere uygun olmadığı ve sonuçların Beykaya ve ark. (2017) ile Akın ve ark. (2016) buldukları sonuçlar ile benzerlik gösterdiği saptanmıştır.

Yoğunluk Değeri: Sütün yoğunluğu sütün bileşiminde bulunan maddelerin etkisine göre değişiklik göstermektedir. Bu nedenle süte yapılan hilelerin tespit edilmesinde sütün yoğunluğundan yararlanılır. İnek sütünün yoğunluğu 1.028-1.039 g $\mathrm{ml}^{-1}$ arasında değişmekte-dir. Sütün yağ miktarı arttıkça yoğunluk düşmekte, protein, laktoz ve mineral madde miktarı arttıkça yoğunluk artmaktadır (Demirci ve ark., 2010). Mardin'de satışa sunulan çiğ sütlerinin yoğunluk değerleri en düşük $1.023 \mathrm{~g} \mathrm{ml}^{-1}$ ile en yüksek $1.033 \mathrm{~g} \mathrm{ml}^{-1}$ olduğunu ve örneklerin 2 tanesinin tebliğde belirtilen en az $1.028 \mathrm{~g} \mathrm{ml}^{-1}$ değerinin altında olduğu belirlenmiştir. Çalışmada çiğ sütlerinin yoğunluk değeri ortalama $1.029 \mathrm{~g} \mathrm{ml}^{-1}$ olarak tespit edilmiştir. $\mathrm{Bu}$ sonuç farklı araştırmacıların inceledikleri çiğ sütlerinin ortalama yoğunluk değerleri ile $1.0291 \mathrm{~g}$ $\mathrm{ml}^{-1}$ (Özrenk ve Bayar, 2008), $1.0290 \mathrm{~g} \mathrm{ml}^{-1}$ (Aydın ve ark., 2010), $1.0287 \mathrm{~g} \mathrm{ml}^{-1}$ (Dilber ve Baran, 2014) ve $1.0282 \mathrm{~g} \mathrm{ml}^{-1}$ (Beykaya ve ark., 2017) benzerlik göstermektedir.

Kurumadde ve Yağsız Kurumadde Miktarı: Sütte suyun dışındaki toplam bileşenler kurumadde olarak isimlendirilir. Süte yapılan bazı hileler kurumadde miktarının değişmesine neden olabildiğinden dolayı önemli bir gösterge olarak kabul edilmektedir (Kurt ve ark., 1981). Bu nedenle süt kurumadde değerlendirilmesi kurumadde ve yağsız kurumadde miktarı şeklinde yapılabilmektedir. Çalışmada incelenen örneklerin kurumadde miktarı en düşük \%10.96, en yüksek \%13.85 ve ortalama \%12.46 olarak tespit edilmiştir. Örneklerin yağsız kurumadde miktarlarının en düşük $\% 8.34$ en yüksek \%9.89 ve ortalama $\% 8.89$ olduğu saptanmıştır. İncelenen örneklerin 4 tanesinin yağsız kurumadde içeriklerinin tebliğde belirtilen değerin (\%8.5) altında olduğu belirlenmiştir.

Beykaya ve ark. (2017) Sivas'ta süt işletmelerine gelen çiğ sütlerin kurumadde ve yağsız kurumadde miktarlarının sırasıyla en düşük \%10.00 ve $\% 7.33$, en yüksek $\% 15.40$ ve $\% 9.80$ ve ortalama $\% 12.73$ ve $\% 8.40$ olduğunu belirlemişlerdir. Göncü ve ark. (2017) Şanlıurfa'da satışa sunulan sokak sütlerinin ortalama kurumadde ve yağsız kurumadde miktarlılarının sırasıyla kış mevsiminde $\% 11.51$ ve \% 8.49 ile yaz mevsiminde \% 10.54 ve \%8.30 olduğunu saptamışlardır. Mardin'de satışa sunulan çiğ sütlerinin ortalama kurumadde miktarlarının Beykaya ve ark. (2017) bulduğu değere benzer, Göncü ark. (2017) bulduğu değerden yüksek olduğu; örneklerin ortalama yağsız kurumadde miktarının ise her iki araştırmacının bulduğu değerden yüksek olduğu belirlenmiştir.

Yağ miktarı: Sütün değerli besin maddelerinden olan süt yağının sütteki miktarı hayvanın ırkına ve yediği yemin kimyasal bileşimine göre değişebilmektedir (Metin, 1998). Süt yağının serumda gevşek bir yapıda olması ve özgül ağırlığının süttün diğer bileşenlerinden daha düşük olması süt yağının sütten çekilmesini kolaylaştırmakta ve sütte su katılması yağın miktarının azalmasına neden olmaktadır (Sezgin ve ark., 1993). Mardin'de satışa sunulan çiğ sütlerinin yağ miktarlarının $\% 2.00$ ile $\% 4.50$ arasında ve ortalama yağ miktarını ise \%3.57 olduğu, örneklerin 11 tanesinin tebliğde belirtilen değere uygun olmadığı tespit edilmiştir. Yapılan diğer çalışmalarda çiğ sütlerinin yağ içerikleri incelediğinde çalışmamızda belirlenen ortalama yağ miktarının Toruk (2006)'un çalışmasında bulduğu değerden (\%3.17) yüksek, Kesenkaş ve Akbulut (2010) (\%3.79), Kaşıkçı (2012) (\% 5.68) ve Diler ve Baran (2017)'ın (\%3.60) çalışmalarında buldukları değerlerden düşük olduğu belirlenmiştir. 
Protein miktarı:Sütteki protein oranın üzerinde hayvanın beslenmesi, ırkı, laktasyon dönemi ve süt verim düzeyi gibi etmenlerin etkisi bulunmaktadır (Şekerden ve Özkütük, 1995; Yalçın, 1981). Mardin'de satışa sunulan çiğ sütlerinin protein miktarının \%2.41 ile \%3.66 arasında değiştiği, ortalama değerin \%3.07 olduğu ve 9 adet çiğ süt örneğinin protein miktarının tebliğde belirtilen \%2.8 değerinin altında olduğu tespit edilmiştir. Kesenkaş ve Akbulut (2010) İzmir'de satılan sokak sütleri ile çiftlik sütlerinin maksimum, minimum ve ortalama protein miktarını sırasıyla \%3.74, 2.67 ve 3.31 ile \%3.48, 2.65 ve 3.12 olduğunu belirlemişlerdir. Benzer çalışmalarda çiğ süt örneklerinin ortalama protein miktarının \%2.98 (Türkoğlu ve ark., 2003), \%3.06 (Önal, 2005) ve \%3.11 (Diler ve Baran, 2014) olduğu bildirilmiştir.

Kül miktarı:Çeşitli makro ve iz elementleri bünyesinde bulunduran süt, özellikle $C a$ ve $P$ bakımından iyi bir besin kaynağıdır Normal sütte kül miktarı yaklaşık \% 0.7 civarındadır (Kurt ve ark., 1981). Mardin'de satışa sunulan çiğ sütlerin kül miktarının \%0.61 ile \%0.83 arasında, ortalama değerin \%0.72 olduğu belirlenmiştir. Türkoğlu ve ark. (2003) çalışmasında incelenen sokak sütlerinin kül miktarlarının \%0.42-0.77 arasında değiştiğini, ortalama değerin \%0.67 olduğunu bildirmişlerdir. Diler ve Baran (2014) Erzurum'da küçük ölçekli işletmelerin süt tanklarından alınan çiğ süt örneklerinin kül miktarını ortalama $\% 0.78$ olarak saptamışlardır.

Toplam aerob mezofilik bakteri sayısı: İnsan sağ|ığı için yararlı bir besin kaynağı olan süt sağlıklı memede hijyenik olarak üretilse de sağımın ve depolama işleminin hijyenik olmayan ortamda yapılması sütün mikrobiyolojik yükünün artmasına ve teknolojik açıdan kullanılamaz hale gelmesine neden olabilmektedir. Süt kompleks biyokimyasal yapısı ve yüksek su kapasitesi nedeniyle, mezofilik ve aerob ortamda gelişen çeşitli saprofit ve patojen mikroorganizmalar için uygun besin ortamı oluşturmaktadır.

Mardin'de satışa sunulan süt toplam aerob mezofilik bakteri sayısı (TAMB) incelendiğinde en düşük, en yüksek ve ortalama sayıların sırasıyla 4.30 log kob ml ${ }^{-1}, 8.66$ log kob ml ${ }^{-1}$ ve 6.62 log kob ml $\mathrm{ml}^{-1}$ olduğu saptanmıştır. İlgili tebliğde çiğ inek sütünün toplam canlı bakteri sayısının $30^{\circ} \mathrm{C}^{\prime}$ de 5.00 log kob $\mathrm{ml}^{-1}$ den daha düşük olması gerektiği bildirilmiştir. Çalışmada incelen çiğ süt örneklerinin 37 tanesinin bu değere uygun olmadığı tespit edilmiştir. Çalışmamızda sokak sütlerinde belirlenen TAMB sayısı diğer araştırmacılar tarafından bildirilen 8.50 log kob ml ${ }^{-1}$ (Şekerden ve Özkütük, 1995), $7.38 \mathrm{log}$ kob $\mathrm{ml}^{-1}$ (Dede, 2000) ve 7.17 log kob $\mathrm{ml}^{-1}$ (Beykaya ve ark.,2017) değerlerinden düşük, $5.29 \mathrm{log}$ kob ml-1
(Diler ve Baran, 2014) değerden yüksek bulunmuştur.

Koliform bakteri sayısı: Enterobacteriaceae familyası içinde yer alan koliform grup bakterilerin gıdalarda bulunması; kötü sanitasyon koşullarının, yetersiz veya yanlış pastörizasyon uygulamalarının, pişirme ve pastörizasyon sonrası tekrar bulaşma olduğunun bir göstergesi olarak kabul edilmektedir.

Çalışmada incelenen sokak sütlerindeki koliform bakteri sayısının $2.00 \mathrm{log} \mathrm{kob} \mathrm{ml}^{-1}$ ile 6.75 log kob ml-1 arasında ve ortalama 4.98 log kob ml-1 olduğu saptanmıştır. Yapılan diğer çalışmalarda çiğ süt örneklerinde ortalama koliform bakteri sayısı Atasoy ve ark. (2003) tarafından 3.83 log kob ml${ }^{-1}$, Kesenkaş ve Akbulut (2010) tarafından 3.70 log kob $\mathrm{ml}^{-1}$ olarak bildirilmiştir. Mardin'de satışa sunulan çiğ süt örneklerindeki koliform bakteri sayısının Kesenkaş ve Akbulut (2010) ile Atasoy ve ark. (2003) belirlediği değerlerden yüksek olduğu saptanmıştır.

Maya-Küf sayısı: Mardin'de satışa sunulan sokak sütlerinde maya-küf sayısının $3.00 \mathrm{log}$ kob ml${ }^{1}$ ile $7.65 \mathrm{log}$ kob $\mathrm{ml}^{-1}$ arasında ve ortalama değerin $4.87 \mathrm{log} \mathrm{kob} \mathrm{ml}^{-1}$ olduğu tespit edilmiştir. Yapılan benzer çalışmalarda çiğ sütlerde ortalama maya-küf sayısı 3.33 log kob ml-1 (Kesenkaş ve Akbulut, 2010) ve 5.57 log kob ml-1 (Beykaya ve ark., 2017) olarak saptanmıştır. Analiz sonucu Mardin'den çiğ süt örneklerinin ortalama maya-küf sayısının Kesenkaş ve Akbulut (2010)'un buldukları değerden yüksek, Beykaya ve ark. (2017)'ın buldukları değerden düşük olduğu belirlenmiştir.

Ülkemizde süt endüstrisindeki gelişmelere bağ lı olarak süt kalitesi ile hijyen kurallarına olan dikkatin artmasına rağmen tüketicilerin bir kısmının yerel perakendecilerde satılan çiğ süttün daha saf, taze ve doğal olduğunu düşünmesi, fiyatının daha düşük olması ve tüketiciye kolaylıkla ulaşılabiliyor olması çiğ süt satışının yaygın olmasına neden olmaktadır. Mardin'de farklı satış noktalarından toplanan 40 adet çiğ süt örneğinin gerek fizikokimyasal ve gerekse mikrobiyolojik özellikler açısından 38 tanesinin (yani \%95'inin) Türk Gıda Kodeksi Çiğ Sütün Arzına Dair Tebliğ'de belirtilen değerlere uygun olmadığı saptanmıştır. \%22.50'sinin titrasyon asitliği, \%5'inin yoğunluk, \%10'nun yağsız kurumadde, \% 27.50'sinin yağ, $\% 22.50$ 'sinin protein ve \% 92.50'sinin toplam canlı bakteri sayısının Türk Gıda Kodeksi Çiğ Sütün Arzına Dair Tebliğ'de belirtilen değerlere uygun olmadığı belirlenmiştir. Örneklerin $\mathrm{pH}$ ve kurumadde değerleri diğer araştırmacıların sonuçları ile benzer bulunurken, kül, koliform bakteri sayısı ve maya-küf sayısı değerleri değişkenlik göstermiştir.

Çalışmada elde edilen veriler genel olarak benzerlik göstermektedir. Ancak özellikle örneklerdeki TAMB sayısının ve asitlik değerlerinin 
yüksek oluşu sütlerin hijyenik olmayan koşullarda depolandığının altını çizmektedir. Bu sonuçlar ışığında Mardin'de perakendeciler tarafından satışa sunulan çiğ sütlerin fizikokimyasal ve mikrobiyal kalitelerinin iyi olmadığı belirlenmiştir. Bu nedenle perakendeciler tarafından satışa sunulan çiğ sütlere ait kontrollerin artırılarak halk sağlığı açısından risk oluşturması engellenmesi gerekmektedir.

\section{Kaynaklar}

Akın MS, Yapık Ö, Akın MB, 2016: Adıyaman ilinde süt üretim çiftliklerinden ve toplayıcılardan sağlanan sütlerin bazı özellikleri. Harran Tar ve Gıda Bil Derg 20(4), 253-265.

Anonim, 1989: Çiğ Süt Standardı. TS1018. Türk Standartlar Enstitüsü, Ankara.

Anonim, 2016: Ulusal Süt Konseyi. https://ulusalsutkonseyi.org.tr/kategori/raporlar/su t-konseyi-raporlari/. Erişim tarihi; 26/03/2019.

Anonim, 2017: Çiğ sütün arzına dair tebliğ (No: 2017/20) 27 Nisan 2017 tarihli Resmi Gazete, Sayı: 30050.

Atasoy F, Türkoğlu H, Özer B, 2003: Şanlıurfa ilinde üretilen ve satışa sunulan süt, yoğurt ve urfa peynirlerinin bazı mikrobiyolojik özelikleri. Harran Üni Ziraat Fak. Derg, 7(3-4), 77-83.

Aydın S, Çetinkaya A, Bayrakçı E, 2010: Kars ilinde üretilen inek sütlerinin bazı kimyasal özellikleri. İçinde: Ulusal Meslek Yüksekokulları Öğrenci Sempoz, Düzce, 1-7.

Beykaya M, Özbey A, Yıldırım Z, 2017: Sivas ilindeki bazı süt işletmelerine gelen sütlerin fiziksel, kimyasal ve mikrobiyolojik özelliklerinin belirlenmesi. Türk Tarım Gıda Bil ve Tek Derg 5(4), 388-396.

Dede C, 2000: İstanbul'da satılan sokak sütlerinin mikrobiyolojik olarak incelenmesi. Yüksek Lisans Tezi, Gebze İleri Teknoloji Enstitüsü Mühendislik ve Fen Bilimleri Enstitüsü Kocaeli.

Demirci $M$, Öksüz Ö, Şimşek $O$, Kurultay Ş, Kıvanç $M$, Gündüz HH, Uçan N, 2010: Süt ve Süt Ürünlerinin Kalite Kontrolü. Eskişehir. Türkiye.

Diler A, Baran A, 2014: Erzurum'un Hınıs ilçesi çevresindeki küçük ölçekli işletme tank sütlerinden alınan çiğ süt örneklerinin bazı kalite özelliklerinin belirlenmesi. Alınteri, 26 (B), 18-24.

Fox PF, McWeeney PLH, 2003: In Chapter 1: Milk Proteins: General and Historical Aspects. In: Advanced Dairy Chemistry Volume 1 (Third Edition Part A). New York, USA.

Göncü B, Çelikel A, Akın MB, Akın MS, 2017: Şanlıurfa'da satışa sunulan sokak sütlerinin bazı kimyasal ve mikrobiyolojik özelliklerinin belirlenmesi üzerine bir araştırma. Harran Üni Müh Derg 2(2), 15-23.

IDF, 1982: Determination of the total solid content (cheese and processed cheese). IDF Standard: 4A.Brussels: International Dairy Federation.

Kaşıkçı M, 2012: Sivas ili Yıldızeli ilçesinde halk elinde yetiştirilen esmer sığırların çiğ süt kompozisyonu ve somatik hücre sayısının belirlenmesi. Yüksek Lisans Tezi, Gaziosmanpaşa Üniversitesi Fen Bilimleri Enstitüsü Zootekni Anabilim Dalı, Tokat.
Kesenkaş H, Akbulut N, 2010: İzmir ilinde satılan sokak sütleri ile orta ve büyük ölçekli çiftliklerde üretilen sütlerin özelliklerinin belirlenmesi. Ege Üni Ziraat Fak Derg, 47(2): 161-169.

Köşker Ö, Tunail N, 1985: Süt ve Mamulleri Mikrobiyolojisi ve Hijyeni Uygulama Klavuzu. Ankara Üniversitesi Ziraat Fakültesi Yay. No: 985, Uygulama Kılavuzu No: 217, Ankara.

Kurt A, Çakmakçı S, Çağlar A, 1993: Süt ve Mamulleri Muayene ve Analiz Metotları Rehberi. Erzurum, Türkiye.

Kurt A, Demirci M, Kurdal E, 1981: Erzurum piyasasında satılan sütlerin, özellikleri ve bu sütlerin çeşitli hile yöntemlerinin incelenmesi. Gıda, 6(8), 15-19.

Maijala K, 2000: Cow milk and human development and well-being. Livest Prod Sci 65, 1-18.

Metin M, 1998: Süt Teknolojisi. Bornova, İzmir.

Metin $M$, 2005: Süt teknolojisi: Sütün Bileşimi ve İşlenmesi., İzmir.

Metin M, 2010: Süt ve Mamulleri Analiz Yöntemleri (Duyusal, Fiziksel ve Kimyasal Analizleri), Bornova, İzmir.

Miller GD, Jarvis KJ, McBean LD, 2000: The importance of milk and milk products in the diet. In "Handbook of Dairy Foods and Nutrition", Ed; J. Kroger, NY, USA.

Oysun G, 2011: Süt ve Ürünlerinde Analiz Yöntemleri. Bornova, İzmir.

Önal AR, 2005: Trakya'da özel bir süt işleme tesisi tarafından değerlendiren çiğ sütlerin somatik hücre sayısı ve bazı bileşenlerin tespiti. Yüksek Lisans Tezi, Trakya Üniversitesi, Fen Bilimleri Enstitüsü, Edirne.

Özrenk E, Bayar N, 2008: Konya yöresine ait sütlerin bazı kalite özellikleri. İçinde: Türkiye 10 . Gıda Kongresi. Erzurum. 695-700 ss.

Sezgin E, Atamer M, Koçak C, Yıldırım M, Yıldııım Z, 1993: Ankara'da satılan sokak sütlerinin bazı fiziksel, kimyasal ve mikrobiyolojik özellikleri. Ankara Üniversitesi Ziraat Fakültesi Yayınları, 1331.

Şekerden Ö, Özkütük K, 1995: Büyük Baş Hayvan Yetiştirme. Adana, Türkiye.

Tekinşen C, 1996: Süt Ürünleri Teknolojisi. Konya, Türkiye.

Tokur E, 2006: Ankara'da satılan sokak sütlerinin bazı fiziksel ve kimyasal özelliklerinin belirlenmesi. Yüksek Lisans Tezi, Ankara Üniversitesi Fen Bilimleri Enstitüsü, Ankara.

Türkoğlu H, Atasoy F, Özer B, 2003: Şanlıurfa ilinde üretilen ve satışa sunulan süt yoğurt ve urfa peynirlerinin bazı kimyasal özelikleri. Harran Üni. Ziraat Fak. Derg., 7(3-4), 69-76.

TÜIK, 2018: TÜiK, https://biruni.tuik.gov.tr/bolgeselistatistik/degiskenlerUzerindenSorgula.do Erişim tarihi: 26-03-2019.

Yalçın BC, 1981: Genel Zootekni. İstanbul, Türkiye

*Yazışma Adresi: Aslı ÇELiKEL GÜNGÖR

Mardin Artuklu Üniversitesi, Turizm Fakültesi, Gastronomi ve Mutfak Sanatları Bölümü, Mardin, Türkiye

e-mail: acelikel2@gmail.com 